\title{
Evaluation of the biological quality of defatted pequi (Caryocar brasiliense Cambess) seed flour protein supplemented with lysine to rats (Rattus norvegicus)
}

\author{
Avaliação da qualidade biológica da proteina \\ da farinha da semente do pequi (Caryocar \\ brasiliense Cambess) desengordurada \\ e suplementada com lisina em \\ ratos (Rattus norvegicus)
}

Miliane Martins de Andrade FAGUNDES ${ }^{1}$ (iD) 0000-0003-4109-4333

Ana Maria Fernandes VIANA2 (iD) 0000-0002-7685-2854

Mayara Medeiros de Freitas CARVALHO2 (iD) 00000-0003-1147-2655

Marcelo Eustáquio SILVA ${ }^{3}$ (D) 0000-0001-5807-6778

\section{A B S T R A C T}

\section{Objective}

In the biome of the Brazilian Cerrado, there are a lot of fruit tree species that stand out for their sensory quality and for presenting potentialities in the market of pulp and almond. Among these species, the pequi deserves

${ }^{1}$ Universidade Federal de Ouro Preto, Escola de Nutrição, Programa de Pós-Graduação em Saúde e Nutrição. Campus Universitário, s/n., Morro do Cruzeiro, 35400-000, Ouro Preto, MG, Brasil. Correspondence to: MMA FAGUNDES. E-mail: <milianefagundes@yahoo.com.br>.

2 Universidade Federal de Ouro Preto, Núcleo de Pesquisas em Ciências Biológicas, Programa de Pós-Graduação em Ciências Biológicas. Ouro Preto, MG, Brasil.

${ }^{3}$ Universidade Federal de Ouro Preto, Escola de Nutrição, Departamento de Alimentos. Ouro Preto, MG, Brasil. Article elaborated from the dissertation by MMA FAGUNDES, entitled "Avaliação da qualidade biológica da proteína da farinha da semente do pequi (Caryocar brasiliense Cambess) desengordurada e suplementada com lisina em ratos (Rattus norvegicus)". Universidade Federal de Ouro Preto; 2017.

\footnotetext{
How to cite this article
}

Fagundes MMA, Viana AMF, Carvalho MMF, Silva ME. Evaluation of the biological quality of defatted pequi (Caryocar brasiliense Cambess) seed flour protein supplemented with lysine to rats (Rattus norvegicus). Rev Nutr. 2019;32:e180129. http://dx.doi.org/10.1590/1678-9865201932e180129 
attention because it has an almond rich in proteins and that is little explored. The aim of this study was to evaluate the biological quality of defatted pequi seed flour supplemented with lysine.

\section{Methods}

Two designs were done in this study; in the first, the animals were divided into four diet groups: control, proteinfree, defatted pequi seed flour and defatted pequi seed flour supplemented with lysine. The protein-free diet was exempt of proteins and the other diets had a protein content of $10 \%$ and differed in protein source (casein: control diet or defatted pequi seed flour: test diets). The experiment lasted for 14 days. In the second design, 36 animals were used and followed-up for 28 days. The division of the experimental groups was kept, except for the protein-free diet group, which was excluded. By the end of the test, the animals were anaesthetised and euthanized.

\section{Results}

The results showed that the protein efficiency ratio of the control group was significantly higher than the other groups. For the other indices, the groups that received defatted pequi seed flour did not differ statistically among themselves.

\section{Conclusion}

These findings have shown an effect of supplementation on the protein efficiency ratio when comparing the test diets, however, when compared to the control group, no improvement was found.

Keyword: Pequi seed. Protein quality. Rats.

\section{R E S U M O}

\section{Objetivo}

O bioma cerrado é rico em espécies frutiferas que destacam-se por suas qualidades sensoriais e por apresentarem potencialidades no mercado de polpas e amêndoas. Dentre essas espécies, o pequi merece atenção porque possui uma amêndoa rica em proteínas e que é pouco explorada. Este estudo teve como objetivo avaliar a qualidade biológica da farinha da semente do pequi desengordurada e suplementada com lisina.

\section{Métodos}

Neste estudo foram feitos dois delineamentos: no primeiro os animais foram divididos em quatro grupos: controle, aprotéico, farinha da semente do pequi desengordurada e farinha da semente do pequi desengordurada suplementada com lisina. A dieta aprotéica era isenta de proteínas e as demais dietas apresentavam um teor de 10\% de proteínas e diferiram quanto à fonte protéica (caseína: dieta controle e farinha da semente do pequi desengordurada: dietas testes). Esse experimento teve duração de 14 dias. No segundo delineamento, utilizou-se 36 animais que foram acompanhados por 28 dias, a divisão dos grupos experimentais foi mantida, exceto o grupo dieta aprotéica que foi excluído. Ao final dos experimentos, os animais foram anestesiados e eutanasiados.

\section{Resultados}

Os resultados mostraram que o coeficiente de eficiência protéica do grupo controle foi significativamente superior aos demais grupos. Para os demais índices biológicos de avaliação da qualidade protéica, os grupos que receberam a farinha da semente do pequi desengordurada não diferiram estatisticamente entre si.

\section{Conclusão}

Os achados mostraram um efeito da suplementação no coeficiente de eficiência protéica quando comparamos as dietas testes, no entanto, quando comparado ao grupo controle, não houve melhora.

Palavras-chave: Semente de pequi. Qualidade protéica. Ratos.

\section{N TROD U C T I O N}

Knowledge of the chemical composition of native species helps to understand nutrition and biodiversity, especially in terms of food production and processing for human consumption [1]. In the 
Brazilian cerrado, the second largest biome in Brazil, there are several native fruit species that present potential for use in human nutrition, and in this context pequi fruit (Caryocar brasiliense Cambess) has an edible seed that is not consumed, even by the local population [2].

The pequi is a typical fruit of the Brazilian cerrado, constituted by a pericarp of greenish coloration; an external mesocarp (pulp with grayish brown); an internal mesocarp, with yellowish color and representing the edible pulp of the fruit. The endocarp, which is prickly, protects the edible seed, which is coated by a thin, brown integument [3-7]. The pulp of in natura pequi fruit has a high lipid content (19.60\% to $33.40 \%$ ) and is also a good source of dietary fiber $(10.02 \%$ to $11.20 \%)$ $[3,8-10]$. Therefore, this fruit exerts a great influence on both eating habits and income of the inhabitants of the Brazilian cerrado. It is an indispensable product in the diet of the populations that live in the areas of occurrence of the species because it provides part of the energy and nutritional needs, mainly for low-income families [11].

In addition to the pulp, the pequi fruit has a seed that is rich in nutrients and which can be better utilized as a food source. Typically, edible seeds are rich in lipids, sources of protein and also contain vitamins and minerals in considerable amounts. These can also be a good source of fibers [12]. The pequi seed is white and has a characteristic flavor. As well as the pulp, it is also edible, being used in natura or in several preparations like sweets, farofas (toasted cassava flour mixture), paçocas (a candy made out of ground peanuts, sugar and salt) and snacks $[5,13,14]$. It has a high content of lipids, which allows the extraction of a clear, good quality oil that has been used in the cosmetics industry for the production of beauty creams and soaps as well as in the production of regular soap $[15,16]$.

A striking feature of pequi seed is its high protein content, around 25\% [9]. However, few data on the amino acid profile and nutritional benefits of this seed are available, therefore, it is very important to determine the protein quality of the seed [2].

It is known that proteins of plant origin do not always present an adequate qualitative and quantitative profile of amino acids, being considered incomplete proteins because they have deficiencies in one or more essential amino acids. Deficiencies in the amino acid profile of proteins can be corrected through the following methods: addition of small amounts of another type of protein that is rich in the first limiting amino acid; through complementation, in which the combination of specific foods is made and the mixture of the proteins of these foods causes that the deficiencies of one are compensated by the excesses of the same amino acids of others; and through the addition of the first amino acid limiting, which was the option used in the present study $[17,18]$.

Considering that pequi seed is rich in proteins, and that proteins play important roles in the body, chemical and biological methods were used to determine the protein quality of the pequi seed [19-21]. Chemical methods are used to evaluate protein quality because they determine the composition of amino acids and enable certain correlations, such as the determination of the limiting amino acid through the Chemical Score (CS) and the calculation of the amino acid chemical score corrected by protein digestibility (PDCAAS, Protein Digestibility-Corrected Amino Acid Score) [22-24]. The biological methods used to determine the nutritional value of a protein are based on the response of an organism to the intake of the studied protein. The most commonly used biological indices are the Protein Efficiency Ratio (PER), the Net Protein Ratio (NPR) [25-28], the True Digestibility (TD) [29,30], the Net Protein Utilization (NPU) [31-33] and the Apparent Nitrogen Balance (BNap).

Based on this information and with the purpose of valuing and stimulating the consumption of regional foods, the objective of this study was to evaluate the biological quality of the protein of 
defatted pequi seed flour supplemented with lysine, through the analysis of nutritional parameters taken from tests with young animals.

\section{METHODS}

\section{Samples of pequi seeds}

Pequi seeds were obtained in Japonvar, a city located in the north of the state of Minas Gerais, Brazil. The seeds were ground until obtaining a homogeneous flour that was used in the analysis of the centesimal, mineral and amino acid composition. Afterwards, the flour was defatted by direct extraction with petroleum ether in Soxhlet [34], dried in a ventilated oven at $45^{\circ} \mathrm{C}$ for 72 hours and kept under refrigeration until determination of the composition and preparation of the diets.

\section{Centesimal composition}

The determination of the centesimal composition of the pequi seed and of Defatted Pequi Seed Flour (DPSF) was carried out at the Laboratory of Bromatology of the School of Nutrition, Universidade Federal de Ouro Preto (UFOP, Federal University of Ouro Preto). The determination of proteins, lipids, ashes and moisture were performed in triplicate, in accordance with the Adolfo Lutz Institute [34]. Total dietary fiber was determined by enzymatic-gravimetric method, in accordance with the Association of Official Analytical Chemists [35]. The amount of carbohydrates in the sample was obtained by difference from the other components, i.e., the value 100 is subtracted from the sum of the values obtained for proteins, lipids, moisture, ash and fiber.

\section{Amino acid profile}

The composition of amino acids was determined at the Centro de Ciência e Qualidade de Alimentos (CCQA, Center for Food Science and Quality) of the Instituto de Tecnologia de Alimentos (ITAL, Institute of Food Technology), in the city of Campinas, Brazil [36-38].

\section{Mineral composition}

To quantify the levels of Sodium (Na), Potassium (K) and Phosphorus (P), 200mg of the sample was transferred to digestion tubes with $4 \mathrm{~mL}$ P.A. nitric acid ( $65 \%$ purity grade) and slowly heated $\left(20^{\circ} \mathrm{C}\right.$ every 30 minutes) in a digestion block with exhaust system, until reaching $130^{\circ} \mathrm{C}$. After this process, the sample remained at the same temperature for about 4 hours, until it became light yellow. Subsequently, with the sample now at room temperature, $1 \mathrm{~mL}$ of P.A. perchloric acid $(70 \%$ purity grade) was added and heating was resumed as described above. The sample was transferred to a volumetric flask $(50 \mathrm{~mL})$ and volume was completed. The determination of sodium and potassium was performed in the flame photometer, using Na/K 100 parts per million standard. For phosphorus quantification, a standard curve with phosphorus solution $(0.01 \mathrm{mg} / \mathrm{mL})$ was prepared, and the absorbance of the standard curve and the sample was taken at the wavelength of 680 nanometers in the spectrophotometer. To determine the other minerals, the sample was incinerated and the 
ashes obtained were sent to the Laboratory of Atomic Absorption of the Universidade Federal de Minas Gerais (UFMG, Federal University of Minas Gerais). The analyzes were carried out in an atomic absorption spectrophotometer coupled to a graphite furnace [34,35].

\section{Composition of experimental diets}

The isocaloric and isoprotein diets (10\% protein - $100 \mathrm{~g}$ protein $/ 1000 \mathrm{~g}$ diet) were prepared at the beginning of the experiment and followed the specific preparation recommendations from the Association of Official Analytical Chemist (AOAC) (39.133) [39] for biological evaluation of protein quality. According to this recommendation the diets must have (for every 100 grams): enough for $10 \%$ of proteins; $8 \%$ lipids; $1 \%$ blend of vitamins; $5 \%$ blend of minerals; $1 \%$ cellulose (fibers); $5 \%$ water and starch, enough to complete $100 \%$. Prior to the preparation of the diets, the centesimal composition of the defatted pequi seed flour was determined so that the nutrients could be discounted when the ingredients of the diet were added. A protein-free diet was also prepared to be used in the determination of NPR, NPU, TD and BNap. The calculation for determining the amount of lysine to be added in the diet was done using as reference the daily amino acid requirements of children from two to five years of age, according to the Food and Agriculture Organization (FAO) standard [40]. The compositions of the experimental diets are shown in Table 1.

Table 1. Composition of the experimental diets (g/kg of diet) and calories from macronutrients. Ouro Preto (MG), Brazil, 2017.

\begin{tabular}{|c|c|c|c|c|}
\hline \multirow{2}{*}{ Nutrients } & \multicolumn{4}{|c|}{ Diet } \\
\hline & Control & DPSF & DPSFL & Protein-free \\
\hline Casein ( $84.3 \%$ of protein) & 120.0 & - & - & - \\
\hline Pequi seed flour & - & 155.0 & 155.0 & - \\
\hline Soy oil & 80.0 & 80.0 & 80.0 & 80.0 \\
\hline Blend of minerals ${ }^{1}$ & 50.0 & 50.0 & 50.0 & 50.0 \\
\hline Blend of vitamins ${ }^{2}$ & 10.0 & 10.0 & 10.0 & 10.0 \\
\hline Choline & 2.5 & 2.5 & 2.5 & 2.5 \\
\hline Cellulose & 10.0 & 10.0 & 10.0 & 10.0 \\
\hline Water & 50.0 & 50.0 & 50.0 & 50.0 \\
\hline Limiting amino acid (lysine) & - & - & 5.5 & - \\
\hline Starch & 677.5 & 642.5 & 637.0 & 797.5 \\
\hline Caloric value $(\mathrm{Kcal} / \mathrm{Kg})$ & $3,834.4$ & $3,695.2$ & $3,673.2$ & $3,910.0$ \\
\hline \multicolumn{5}{|l|}{ Calories from macronutrients } \\
\hline Carbohydrate (Kcal) & $2,710.0$ & $2,570.0$ & $2,548.0$ & $3,190.0$ \\
\hline Proteins (Kcal) & 404.4 & 405.2 & 405.2 & - \\
\hline Lipids (Kcal) & 720.0 & 720.0 & 720.0 & 720.0 \\
\hline
\end{tabular}

Note: ${ }^{1}$ Blend of minerals (in g/Kg of the blend): Sodium chloride: 139,3; Potassium iodide: 0,79; Magnesium sulfate heptahydrate: 57,3; Calcium carbonate: 381,4; Magnese sulfate monohydrate: 4,01; Iron (II) sulfate heptahydrate: 0,548; Copper (II) sulfate pentahydrate: 0,477; Cobaltous chloride hexahydrate: 0,023; Potassium phosphate monobasic: 389,0.

${ }^{2} \mathrm{Blend}$ of vitamins (in $\mathrm{mg} / \mathrm{Kg}$ of the blend): Retinol acetate-690; cholecalciferol-5; p-amino benzoic acid-10000; inositol-10000; niacin-4000; riboflavin-800; thiamine HCL-500; folic acid-200; biotin-40; cyanocobalamin-3; dl- $\alpha$-tocopherol-6700; sucrose-q.s.p.1000g.

DPSF: Defatted Pequi Seed Flour. DPSFL: Defatted Pequi Seed Flour with Lysine. Kcal: kilogram calorie. Conversion factors: 4Kcal/g proteins, $9 \mathrm{Kcal} / \mathrm{g}$ lipids, 4Kcal/g carbohydrates. 


\section{Experimental design}

Seventy-six recently weaned male Fischer rats from 21 to 23 days old were used, weighing approximately 45 grams, from the Laboratory of Experimental Nutrition of the School of Nutrition of UFOP. The animals were housed individually in metal cages arranged in an environment which allowed for air circulation, with temperature, luminosity and humidity control. Filtered water and food were available at all times. To verify the proposed objectives, two experiments were performed, since the indices for calculating the protein quality have different characteristics, such as the followup time. In addition, when a group of animals that do not receive protein through the diet is included, a shorter period of experimentation is recommended due to the stress caused to the animals, and it is necessary to quantify nitrogen in the carcass for the calculation of the Net Protein Utilization.

In experiment 1, which lasted 14 days, the rats were divided into four groups with 10 animals each. The control group received the standard diet with $10 \%$ protein from casein, the protein-free diet group received a protein-free diet. A diet with $10 \%$ of protein derived from the pequi seed was offered to the Defatted Pequi Seed Flour (DPSF) group, and the Lysine-supplemented Defatted Pequi Seed Flour (DPSFL) group received the same diet as the DPSF group with the addition of lysine, which is the first limiting amino acid of the pequi seed. In experiment 2, the animals were divided into three groups with 12 animals each. The diets offered to each group presented the same composition of the diets of experiment 1, except for the protein-free diet that was not included in this experimental design. The animals were kept under the same conditions as in the first experiment and were followed-up for 28 days.

The animals were weighed weekly for monitoring body mass and calculating weight gain (or loss). Food consumption and fecal collection were evaluated for seven consecutive days from the second week of each experiment. In order to control ingestion and excretion, paper trays were placed under each of the cages, being replaced daily and the separation and weighing of the feces and food leftovers. Concomitantly with this step, the amount of food offered for each animal was also controlled.

At the end of the experiments, the animals were fasted for 12 hours, anesthetized using a vaporizer calibrated with isoflurane ( $3 \%$ to $5 \%$ ) and euthanized by incision of the blood vessels adjacent the brachial plexus to full bleeding. The experiment was approved by the Committee on Ethics in the Use of Animals of the Federal University of Ouro Preto (CEUA/UFOP), protocol No.2015/43.

\section{Protein quality evaluation indices}

Methods for evaluating biological protein quality were determined using the formulas described below. The Chemical Score (CS) is given by the ratio: $\mathrm{CS}=(\mathrm{mg}$ of the essential aac per $\mathrm{g}$ of the test protein/mg of the essential aac per $\mathrm{g}$ of the reference protein) $\mathrm{x} 100$. The PDCAAS is calculated by multiplying the lowest chemical score of the essential amino acid by the True Digestibility (TD):PDCAAS=CSXTD. PER and NPR are calculated, respectively: $P E R=($ weight gain $(\mathrm{g}) /$ protein consumed $(\mathrm{g})$ ) and $\mathrm{NPR}=$ (weight gain in the test group (g)- weight loss in the protein-free group $(\mathrm{g}) /$ protein consumed by the test group $(\mathrm{g})$ ). The corrected PER=[(PER of the test group/PER of the control group)×2.5] was also determined. For the calculation of Apparent Nitrogen Balance (BNap), True Digestibility (TD) and Net Protein Utilization (NPU), it was necessary to quantify the Ingested Nitrogen (NI), Fecal Nitrogen (NF) and Carcass Nitrogen (NC), and the following formulas were used: $\mathrm{BNap}=\mathrm{NI}(\mathrm{g})-[\mathrm{NF}$ (test group)(g)-NF(protein-free group)(g)]; TD=\{NI(g)-[NF(test group)(g)-NF(protein- 
free group)(g)]/NI(test group)(g) $\} \times 100$ and NPU $=\{[N C$ (test group)g)-NC(protein-free group)(g)]/NI(test group)(g)\}×100.

\section{Statistical analysis}

Data were submitted to the Kolmogorov-Smirnov normality test. Data with parametric distribution were treated by the One-Way ANOVA test, Tukey post-hoc test and presented as Mean \pm Standard Deviation $(\mathrm{M} \pm \mathrm{SD})$. Data with non-parametric distribution were evaluated through the Kruskal-Wallis test followed by Dunn post-hoc test and were expressed as median and interquartile range. The differences were considered significant when $p \leq 0.05$. The GraphPad Prisma software, v5.00 compatible with the Windows operating system (San Diego, California, United States) was used for the analysis.

\section{RESULTS AND DISCUSSION}

The results of the centesimal composition of the pequi seed and the defatted pequi seed flour used in this study are shown in Table 2. The concentration of lipids found in the pequi seed was

Table 2. Centesimal composition, caloric value and mineral composition of the pequi seed and defatted pequi seed flour. Ouro Preto (MG), Brazil, 2017.

\begin{tabular}{|c|c|c|}
\hline Nutrients (g/100g) & In natura seed & Defatted pequi seed flour \\
\hline Moisture & $3.79 \pm 0.06$ & $7.17 \pm 0.37$ \\
\hline Proteins & $25.28 \pm 0.45$ & $65.47 \pm 0.47$ \\
\hline Lipids & $55.42 \pm 0.22$ & $3.05 \pm 0.01$ \\
\hline Ashes & $3.79 \pm 0.05$ & $9.77 \pm 0.07$ \\
\hline Total food fiber & $8.20 \pm 0.55$ & $15.58 \pm 1.28$ \\
\hline Carbohydrates $^{1}$ & 3.52 & Negligible amount \\
\hline Total caloric value (Kcal) & 613.98 & 289.33 \\
\hline \multicolumn{3}{|l|}{ Minerals (mg/100g sample) } \\
\hline Calcium & 138.81 & 231.35 \\
\hline Magnesium & 356.19 & 593.65 \\
\hline Sodium & 24.80 & 41.33 \\
\hline Potassium & 817.27 & $1,362.12$ \\
\hline Phosphor & 745.67 & $1,242.78$ \\
\hline Iron & 2.50 & 4.17 \\
\hline Copper & 1.47 & 2.45 \\
\hline Chrome & 42.71 & 71.18 \\
\hline Cobalt & 0.42 & 0.70 \\
\hline Barium & 1.06 & 1.77 \\
\hline Cadmium & 0.22 & 0.37 \\
\hline Aluminum & 0.85 & 1.42 \\
\hline Lead & 1.10 & 1.83 \\
\hline
\end{tabular}

Note: ${ }^{1}$ Carbohydrate $=100$-(moisture+proteins+lipids+ash+total dietary fiber).

The macronutrients were analyzed in triplicates. Values expressed as Mean \pm Standard Deviation. Conversion factors: $4 \mathrm{Kcal} / \mathrm{g}$ proteins, $4 \mathrm{Kcal} / \mathrm{g}$ carbohydrates and $9 \mathrm{Kcal} / \mathrm{g}$ lipids. 
$55.4 \%$ and the protein content was $25.3 \%$. In the defatted flour, the lipids represented only $3.0 \%$ of the sample and the proteins, $65.5 \%$. Significant amounts of total dietary fiber were found both in the seed and the flour, representing $8.2 \%$ and $15.6 \%$, respectively.

In the pequi seed, high levels of lipids are observed, which according to Lima et al. [9] is the major component of this seed, accounting for $51.5 \%$ of its composition. In the present study, we found a percentage of lipids of 55.4\%, a value close to that reported by Lima. Other studies corroborate with this finding, Ramos \& Souza [7] found a mean lipid content of $48.5 \%$ in the pequi seed of the species Caryocar coriaceum and Sousa et al. [41] reported a proportion of lipids of $50.0 \%$ for the pequi seed of the Caryocar brasiliense species. Regarding the protein content of the pequi seed, the result found in this study showed a protein content of $25.3 \%$, similar to those found by Lima et al. [9] and Sousa et al. [41], who found 25.3\% and 29.6\% respectively. Damiani et al. [5] found a protein content of $13.4 \%$ for the raw almond, differing from our study. Ramos \& Souza [7] worked with pequi seeds of the Caryocar coriaceum species, and also found a protein concentration similar to that of this study, $27.1 \%$. The average value of the amount of fibers found in this study was $8.2 \mathrm{~g} / 100 \mathrm{~g}$, close to that reported in Sousa et al. [41], 10.4g/100 g and higher than that described by Lima et al. [9], which was $2.2 \mathrm{~g} / 100 \mathrm{~g}$. These results reinforce the nutritional importance of the pequi seed and the need for further studies to stimulate the consumption and use of this seed as an extra option in the almond market.

In the analysis of the mineral content of the pequi seed (Table 2), it was observed that the sodium content found in this study was $24.80 \mathrm{mg}$ per 100 grams of the seed, which corroborates with the study of Freitas \& Naves [42], which reports that nuts and edible seeds have reduced sodium concentration. In addition, the potassium, phosphorus, magnesium, copper and chromium contents found in the pequi seed meet the Recommended Daily Intake (IDR) minimum recommendation of $15 \%$, therefore pequi seeds can be considered a source of these minerals [43-45]. For some microminerals (chromium, barium, aluminum, cobalt, cadmium and lead) no data were found in the literature concerning the pequi seed.

The amino acid composition is an important chemical property of proteins, and as such represents one of the determinants of the seed's nutritional value $[46,47]$. Based on the essential amino acid requirement model for preschoolers from 2 to 5 years old [40], the chemical lysine score found in our study corresponds to only $39 \%$ of the requirement, and is therefore considered the first limiting amino acid of the pequi seed (Table 3). It should be noted that the seed was a good source of valine, methionine and cystine, isoleucine, histidine, phenylalanine and tyrosine, with values higher than those recommended by the FAO in 1985 [40]. Lysine was also considered the first limiting amino acid of the pequi seed in the study of Sousa et al. [41] and several nuts, such as the Brazil nut (Bertholetia excelssa), cashew nut (Anacardium occidentale), hazelnut (Corylus hazelnut), pine nuts (Pinus pinea) and walnuts (Juglans regia), according to Venkatachalan \& Sathe [12]. Due to these findings, the study of lysine supplementation in defatted pequi seed flour was proposed.

\section{Design 1}

The digestibility is the first factor that reflects the efficiency of the protein utilization of the diet, therefore, it can be considered a conditioner of its quality [48]. The true digestibility of the casein diet of our study (94.3\%) presented in table 4 was higher and statistically different from the other diets, whose values were $86.9 \%$ for the DPSF diet and $89.4 \%$ for the DPSFL diet. Sousa et al. [41] evaluated 
Table 3. Composition of amino acids, chemical score and PDCAAS of the pequi seed. Ouro Preto (MG), Brazil, 2017.

\begin{tabular}{|c|c|c|c|c|}
\hline Amino acids & $\mathrm{mg} / \mathrm{g}$ of protein & FAO standard (FAOMHO) ${ }^{2}$ & Chemical Score (\%) & PDCAAS (\%) \\
\hline \multicolumn{5}{|l|}{ Essential } \\
\hline Histidin & 24.29 & 19.00 & 127.84 & 111.00 \\
\hline Threonine & 27.13 & 34.00 & 79.79 & 69.00 \\
\hline Valine & 42.27 & 35.00 & 120.78 & 105.00 \\
\hline Methionine + Cystine & 42.59 & 25.00 & 170.35 & 148.00 \\
\hline Isoleucine & 40.38 & 28.00 & 144.21 & 125.00 \\
\hline Leucine & 57.10 & 66.00 & 86.51 & 75.00 \\
\hline Phenylalanine + Tyrosine & 64.35 & 63.00 & 102.15 & 89.00 \\
\hline Lysine $^{1}$ & 22.71 & 58.00 & 39.16 & 34.00 \\
\hline Tryptophan & 10.09 & 11.00 & 91.77 & 80.00 \\
\hline \multicolumn{5}{|l|}{ Non-essential } \\
\hline Aspartic Acid & 88.64 & - & - & - \\
\hline Glutamic Acid & 237.22 & - & - & - \\
\hline Serine & 45.43 & - & - & - \\
\hline Glycine & 37.54 & - & - & - \\
\hline Arginine & 197.79 & - & - & - \\
\hline Alanine & 32.18 & - & - & - \\
\hline Proline & 30.28 & - & - & - \\
\hline
\end{tabular}

Note: ${ }^{1}$ Lysine: the first limiting amino acid; ${ }^{2}$ FAONWHO (1985): Established theoretical standard of essential amino acids for children between 2 and 5 years of age.

FAO: Food and Agriculture Organization; WHO: World Health Organization; PDCAAS: Protein Digestibility-Corrected Amino Acid Score.

the digestibility of the pequi seed and found a value of $88.1 \%$, a result that corroborates the finding in this study. Some studies evaluated the digestibility of other typical seeds from the Brazilian cerrado and found values of true digestibility of $83.5 \%$ for bocaiúva seeds (Acronomia aculeata), $79.4 \%$ for baru seeds (Dipteryx alata), and $88.0 \%$ for Cashew nuts (Anacardium othonianum) $[1,41,49]$. The DPSF and DPSFL diets presented good digestibility, that is, an effective absorption of the amino acids. A digestibility value around $80.0 \%$ to $90.0 \%$, which is considered a good percentage of amino acid uptake, is observed in some plant products and is what has been found for the pequi seed in the present study [30,50-52].

In relation to the NPR, it was verified that the addition of lysine did not result in statistical difference between the DPSF and DPSFL groups. The food and protein intake of the groups that received the pequi seed did not differ significantly and the same could be observed for the weight gain. The control group presented statistically higher averages of protein intake, weight gain and NPR, however, it was observed that the pequi seed proteins were able to guarantee the maintenance of the animals' weight. Sousa et al. [41] found an NPR value of 2.19 \pm 0.29 for the pequi seed, higher than the one found in this study $(1.65 \pm 0.33)$ (Table 4).

It was also determined the apparent nitrogen balance, since it was not possible to collect the urine from the animals for quantification of nitrogen. BNap analysis revealed that the use of pequi seed protein was enough to promote a positive nitrogen balance, which is expected for growing animals. Thus, the ingested nitrogen was superior to the nitrogen excreted in the faeces, evidencing retention of nitrogen. 
Table 4. Food and protein intake, weight gain, nitrogen determination and protein quality indices of animals on protein-free, control, DPSF and DPSFL diets. Ouro Preto (MG), Brazil, 2017.

\begin{tabular}{|c|c|c|c|c|c|c|c|c|c|c|c|c|}
\hline \multirow{3}{*}{ Variables } & \multicolumn{12}{|c|}{ Experimental Groups } \\
\hline & \multicolumn{3}{|c|}{ Protein-free } & \multicolumn{3}{|c|}{ Control } & \multicolumn{3}{|c|}{ DPSF } & \multicolumn{3}{|c|}{ DPSFL } \\
\hline & M & & SD & M & & SD & M & & SD & M & & SD \\
\hline Food intake (g) & 64.68 & \pm & $23.58^{b}$ & 129.30 & \pm & $10.92^{\mathrm{a}}$ & 95.76 & \pm & $25.02^{c}$ & 86.24 & \pm & $22.06^{\text {b.c }}$ \\
\hline Protein intake (g) & & - & & 14.15 & \pm & $1.19^{a}$ & 9.14 & \pm & $2.39^{\mathbf{b}}$ & 8.53 & \pm & $2.18^{b}$ \\
\hline Fecal excretion (g) & 1.19 & \pm & $0.35^{\mathbf{b}}$ & 3.70 & \pm & $0.77^{\mathrm{a}}$ & 6.20 & \pm & $1.66^{\mathrm{c}}$ & 4.82 & \pm & $1.93^{\mathrm{a} . \mathrm{c}}$ \\
\hline Initial Body Weight (g) & 46.90 & \pm & $5.30^{\mathrm{a}}$ & 46.90 & \pm & $5.38^{\mathrm{a}}$ & 46.50 & \pm & $5.12^{\mathrm{a}}$ & 45.60 & \pm & $7.18^{\mathrm{a}}$ \\
\hline Final Body Weight (g) & 32.70 & \pm & $3.74^{\mathrm{b}}$ & 83.90 & \pm & $8.65^{\mathrm{a}}$ & 47.00 & \pm & $7.41^{\mathrm{c}}$ & 46.00 & \pm & $7.82^{c}$ \\
\hline Weight Gain (g) & & - & & 37.00 & \pm & $4.42^{\mathrm{a}}$ & 0.50 & \pm & $3.69^{b}$ & 0.40 & \pm & $4.14^{\mathrm{b}}$ \\
\hline Ingested Nitrogen (g) & & - & & 2.62 & \pm & $0.19^{\mathrm{a}}$ & 1.46 & \pm & $0.38^{\mathbf{b}}$ & 1.36 & \pm & $0.35^{\mathbf{b}}$ \\
\hline Fecal Nitrogen (g) & & - & & 0.17 & \pm & $0.03^{\mathrm{a}}$ & 0.24 & \pm & $0.06^{\mathrm{a}}$ & 0.18 & \pm & $0.07^{\mathrm{a}}$ \\
\hline Carcass Nitrogen (g) & & - & & 2.66 & \pm & $0.27^{\mathrm{a}}$ & 1.49 & \pm & $0.23^{b}$ & 1.46 & \pm & $0.25^{\mathrm{b}}$ \\
\hline NPR & & - & & 3.62 & \pm & $0.15^{a}$ & 1.65 & \pm & $0.33^{\mathbf{b}}$ & 1.80 & \pm & $0.64^{b}$ \\
\hline $\operatorname{TD}(\%)$ & & - & & 94.32 & \pm & $1.24^{\mathrm{a}}$ & 86.96 & \pm & $4.19^{b}$ & 89.47 & \pm & $6.08^{b}$ \\
\hline BNap (g) & & - & & 2.13 & \pm & $0.16^{\mathrm{a}}$ & 1.27 & \pm & $0.35^{\mathbf{b}}$ & 1.23 & \pm & $0.36^{\mathbf{b}}$ \\
\hline NPU (\%) & & - & & 71.23 & \pm & $6.60^{\mathrm{a}}$ & 29.74 & \pm & $14.71^{b}$ & 31.56 & \pm & $18.61^{b}$ \\
\hline
\end{tabular}

Note: Data are presented as Mean \pm Standard Deviation (One-way ANOVA). Significant differences $(p \leq 0.05)$ between the groups are represented by different letters. $\mathrm{n}=10$ animals/group.

DPSF: Defatted Pequi Seed Flour; DPSFL: Defatted Pequi Seed Flour with Lysine; NPR: Net Protein Ratio; TD: True Digestibility; BNap: Apparent Nitrogen Balance; NPU: Net Protein Utilization.

The NPU results of the groups fed with the DPSF and DPSFL diets showed that the quality of the pequi seed protein was lower than casein to promote protein synthesis, since NPU measures how much of the protein ingested is retained in the organism [53]. As observed through digestibility, amino acids may be well absorbed, but may not be involved in protein synthesis, due to a deficiency in some essential amino acids of the pequi seed [54]. The addition of lysine did not significantly alter endogenous protein retention, and in addition, animals in the DPSF and DPSFL groups consumed significantly lower amounts of nitrogen (protein), which may explain the low NPU values. No data were found in the literature regarding the NPU of the pequi seed.

\section{Design 2}

The values obtained in the second design for the PER and the corrected PER differed statistically among the diets evaluated (Table 5). The PER of the group fed with the casein diet showed to be significantly superior to the other groups, which may be justified by the higher food and protein intake and, consequently, higher weight gain by this group. Because it is an animal protein, casein has all the necessary essential amino acids in adequate amounts for the growth and maintenance of the organism [55].

When comparing pequi seed-based diets, the lysine-supplemented diet had a PER value approximately $50 \%$ higher than the PER of the DPSF diet. Observing the PER value of both diets, we can see an effect of supplementation with the first limiting amino acid. Other studies 
Table 5. Food and protein intake, weight gain, PER and corrected PER of animals on control, DPSF and DPSFL diets. Ouro Preto (MG), Brazil, 2017.

\begin{tabular}{lccc}
\hline \multirow{2}{*}{ Variables } & \multicolumn{3}{c}{ Experimental Groups } \\
\cline { 2 - 4 } & Control & DPSF & DPSFL \\
\hline Food intake (g) & $282.20(269.40 ; 305.90)^{\mathbf{a}}$ & $212.10(193.10 ; 215.40)^{\mathbf{b}}$ & $180.60(172.50 ; 191.50)^{\mathbf{b}}$ \\
Protein intake (g) & $30.68(29.50 ; 33.48)^{\mathbf{a}}$ & $20.24(18.42 ; 20.56)^{\mathbf{b}}$ & $17.87(17.07 ; 18.95)^{\mathbf{b}}$ \\
Fecal excretion (g) & $8.82 \pm 0.85^{\mathbf{a}}$ & $14.20 \pm 1.73^{\mathbf{b}}$ & $13.41 \pm 0.96^{\mathbf{b}}$ \\
Initial Body Weight (g) & $44.23 \pm 2.84^{\mathbf{a}}$ & $44.50 \pm 3.31^{\mathbf{a}}$ & $45.18 \pm 2.67^{\mathbf{a}}$ \\
Final Body Weight (g) & $116.4 \pm 7.47^{\mathbf{a}}$ & $51.67 \pm 5.38^{\mathbf{b}}$ & $58.11 \pm 6.93^{\mathbf{b}}$ \\
Weight Gain (g) & $72.15 \pm 8.30^{\mathbf{a}}$ & $7.17 \pm 6.06^{\mathbf{b}}$ & $12.93 \pm 6.50^{\mathbf{b}}$ \\
PER & $2.33 \pm 0.16^{\mathbf{a}}$ & $0.36 \pm 0.30^{\mathbf{b}}$ & $0.73 \pm 0.39^{\mathbf{c}}$ \\
Corrected PER & $2.5^{\mathbf{a}}$ & $0.39 \pm 0.33^{\mathbf{b}}$ & $0.78 \pm 0.42^{\mathbf{c}}$ \\
\hline
\end{tabular}

Note: Data are presented as Mean \pm Standard Deviation (One-way ANOVA) or as median and percentiles (25\% and $75 \%$ ) (Kruskal-Wallis). Significant differences $(p \leq 0.05)$ between the groups are represented by different letters. $n=12$ animals/group.

DPSF: Defatted Pequi Seed Flour. DPSFL: Defatted Pequi Seed Flour with Lysine; PER: Protein Efficiency Ratio; Corrected PER=[(PER of test group/

evaluated the PER of other typical Brazilian cerrado seeds and found values higher than those described in this study. PER values for bocaiúva seed (Acrocomia aculeata), baru seed (Dipteryx alata) and pequi seed (Caryocar brasiliense) were $2.34 \pm 0.25 ; 2.11 \pm 0.19$ and $1.00 \pm 0.19$, respectively $[2,49]$.

\section{CONCLUSION}

The findings contained in this study regarding the centesimal composition of the pequi seed showed that it has significant contents of lipids, proteins, fibers and minerals such as potassium, phosphorus and magnesium, thus representing a food of good nutritional value. The low consumption of food from the diet by the animals that received the pequi seed directly reflected in the results obtained from the biological tests in this study. For the NPR and NPU no differences were observed between the DPSF and DPSFL groups, possibly due to the short experimental period that prevented animals from having a beneficial adaptation. However, for the PER, which among the methods used in this study, is the most demanding one in terms of protein quality, it was observed a positive effect of lysine supplementation, with an increase of approximately $50 \%$ in the value of this index, compared to the non-supplemented group. However, when compared with the control group, lysine supplementation was not satisfactory, which may be related to the fact that pequi protein is deficient in other essential amino acids, such as threonine, leucine and tryptophan. As a perspective for the promotion of the pequi seed, future studies are suggested to be performed with the supplementation including other limiting amino acids in order to achieve a PER closer to the control group.

\section{CONTRIBUTORS}

MMA FAGUNDES, AMF VIANA and MMF CARVALHO Participated in the development and performance of the experimental design; data collection, analysis and discussion, and writing and reviewing the article. ME SILVA was responsible for the development of the project, interpretation of data, and final review of the article. 


\section{ACKNOWLEDGEMENTS}

We would like to thank the Universidade Federal de Ouro Preto (UFOP, Federal University of Ouro Preto) for their support in the development of the project and the Universidade Federal de Minas Gerais (UFMG, Federal University of Minas Gerais) for their support in the analysis of minerals.

\section{REFERENCES}

1. Fernandes DC, Freitas JB, Czeder LP, Naves MMV. Nutritional composition and protein value of the baru (Dipteryx alata Vog.) almond from the Brazilian Savanna. J Sci Food Agric. 2010;90(10):1650-5.

2. Sousa AGO, Fernandes DC, Naves MMV. Eficiência alimentar e qualidade proteica das sementes de baru e pequi procedentes do Cerrado brasileiro. Rev Inst Adolfo Lutz. 2012;71(2):274-80.

3. Alves AM, Fernandes DC, Sousa AGO, Naves RV, Naves MMV. Características físicas e nutricionais de pequis oriundos dos estados de Tocantins, Goiás e Minas Gerais. Braz J Food Technol. 2014;17(3):198-203.

4. Araújo FD. A review of Caryocar brasiliense (Caryocaracea): An economically valuable species of the Central Brazilian Cerrados. Econ Botany.1995;40(1):40-8.

5. Damiani C, Almeida TL, Costa NV, Medeiros NX, Silva AGM, Silva FA, et al. Perfil de ácidos graxos e fatores antinutricionais de amêndoas de pequi crua e torrada. Pesq Agropec Trop. 2013;43(1):71-8.

6. Silva MAP, Medeiros Filho S. Morfologia de fruto, semente e plântula de piqui (Caryocar coriaceum Wittm.). Rev Ciênc Agron. 2006;37(3):320-5.

7. Ramos KMC, Souza VAB. Características físicas e químico-nutricionais de frutos de pequizeiro (Caryocar coriaceum Wittm.) em populações naturais da região meio-norte do Brasil. Rev Bras Frutic. 2011;33(2):500-8.

8. Cordeiro MWS, Cavallieri ALF, Ferri PH, Naves MMV. Características físicas, composição químico-nutricional e dos óleos essenciais da polpa de Caryocar brasiliense nativo do estado de Mato Grosso. Rev Bras Frutic. 2013;35(4):1127-39.

9. Lima A, Silva AMO, Trindade RA, Torres RP, Mancini-Filho J. Composição química e compostos bioativos presentes na polpa e na amêndoa do pequi (Caryocar brasiliense, Camb.). Rev Bras Frutic. 2007;29(3):695-8.

10. Teixeira TN, Esteves EA, Oliveira LG, Oliveira MLP, Santana RC, Dessimoni NAV, et al. Caryocar brasiliense pulp increases serum HDL and reduces hepatic lipid accumulation in rats fed a high fat diet. J Med Plants Res. 2013;7(15):963-9.

11. Oliveira MEB, Guerra NB, Barros LM, Alves RE. Aspectos agronômicos e de qualidade do pequi. Brasília: Embrapa; 2008.

12. Venkatachalam M, Sathe SK. Chemical composition of selected edible nut seeds. J Agric Food Chem. 2006;54(13):4705-14.

13. Cândido PA, Malafaia GC, Rezende ML. A exploração do pequi na região norte de Minas Gerais: abordagem por meio do sistema agroalimentar localizado. Rev Ideas. 2012;5(2):118-38.

14. Oliveira WL, Scariot A. Boas práticas de manejo para o extrativismo sustentável do pequi. Brasília: Embrapa Genetic Resources and Biotechnology; 2010.

15. Oliveira MEB, Guerra NB, Maia AHN, Alves RE, Matos NMS, Sampaio FGM. Características químicas e físico-químicas de pequis da Chapada do Araripe, Ceará. Rev Bras Frutic. 2010;32(1):114-25.

16. Roesler R, Malta LG, Carrasco LC, Holanda RB, Sousa CAS, Pastore GM. Atividade antioxidante de frutas do cerrado. Ciênc Tecnol Aliment. 2007;27(1):53-60.

17. Woolf PJ, Fu LL, Basu A. vProtein: Identifying optimal amino acid complements from plant-based foods. Plos One. 2011;6(4):e18836. http://dx.doi.org/10.1371/journal.pone.0018836

18. Molina SMG, Gaziola SA, Lea PJ, Azevedo RA. Manipulação de cereais para acúmulo de lisina em sementes. Scientia Agric. 2001;58(1):205-11.

19. Alves LF, Rocha MS, Gomes CCF. Avaliação da qualidade protéica da Quinua Real (Chenopodium quinoa Willd) através de métodos biológicos. e-Scientia. 2008;1(1):1-16. 
20. Arentson-Lantz E, Clairmont S, Paddon-Jones D, Tremblay A, Elango R. Protein: A nutrient in focus. Appl Physiol Nutr Metab. 2015;40(8):755-61.

21. Nutten S. Proteins, peptides and amino acids: role in infant nutrition. In: Bhatia J, Shamir R, Vandenplas Y. Protein in neonatal and infant nutrition: Recent updates. 86th ed. Beijing: Nestle Nutr Inst Workshop; 2016. p.1-10.

22. Millward DJ, Layman DK, Tomé D, Schaafsma G. Protein quality assessment: Impact of expanding understanding of protein and amino acid needs for optimal health. Am J Clin Nutr. 2008;87(5):1576-81.

23. Schaafsma G. Advantages and limitations of the protein digestibility-corrected amino acid score (PDCAAS) as a method for evaluating protein quality in human diets. Br J Nutr. 2012;108(Suppl.2):333-6.

24. Wolfe RR. Update on protein intake: Importance of milk proteins for health status of the elderly. Nutr Rev. 2015;73(Suppl.1):41-7.

25. Osborne TB, Mendel LB, Ferry EL. A method of expressing numerically the growth-promoting value of proteins. J Biol Chem. 1919;37:223-9.

26. Angelis RC. Valor nutricional das proteínas: métodos de avaliação. Cad Nutr Soc Bras Alim Nutr. 1995;10(1):8-29.

27. Bender AE, Doel BH. Biological evaluation of proteins: A new aspect. Br J Nutr. 1957;11(2):140-8.

28. Mitchell GV, Jenkins MY, Grundel E. Protein efficiency ratios and net protein rations of selected protein foods. Plant Food Hum Nutr. 1989;39(1):53-8.

29. Gilani GS, Xiao CW, Cockell KA. Impact of antinutritional factors in food proteins on the digestibility of protein and the bioavailability of amino acids and on protein quality. Br J Nutr. 2012;108(Suppl.2):S315-32.

30. Gilani GS, Cockell KA, Sepehr E. Effects of antinutritional factors on protein digestibility and amino acid availability in foods. J AOAC Inter. 2005;88(3):966-87.

31. Miller DS, Bender AE. The determination of the net utilization of proteins by a shortened method. Br J Nutr. 1955;9(4):382-8.

32. Pellet $\mathrm{PL}$, Kaba H. Carcass amino acids of the rat under conditions of determination of the net protein utilization. J Nutr. 1972;102(1):61-8.

33. Lachance PA, Miller GA. Protein quality assessment in the rat: Correlation between whole carcass and hind limb nitrogen concentration. Nutr Rep Int. 1973;7(1):25-31.

34. Instituto Adolfo Lutz. Métodos físico-químicos para análise de alimentos. São Paulo: IAL; 2008. E-book.

35. Association of Official Analytical Chemists. (986.08) (985.29) (960.52): Official methods of analysis of the Association of Official Analytical Chemists. 16th ed. Washington (DC): AOAC; 1997.

36. Spies JR. Determination of tryptophan in proteins. J Anal Chem. 1967;39(12):1412-5.

37. White JA, Hart RJ, Fry JC. An evaluation of the Waters Pico-Tag system for the amino-acid analysis of food materials. J Autom Chem. 1986;8(4):170-7.

38. Hagen SR, Frost B, Augustin J. Precolumn phenylisothiocyanate derivatization and liquid chromatography of amino acids in food. J Assoc Off Anal Chem. 1989;72(6):912-6.

39. Association of Official Analytical Chemists. (39.133): Official methods of analysis of the Association of Official Analytical Chemists.10th ed. Washington (DC): AOAC; 1965.

40. Food and Agriculture Organization. Energy and protein requirements: Report of a joint FAOMHO/UNU expert consultation meeting. Geneva: WHO; 1985.

41. Sousa AGO, Fernandes DC, Alves AM, Freitas JB, Naves MMV. Nutritional quality and protein value of exotic almonds and nut from the Brazilian Savanna compared to peanut. Food Res Inter. 2011;44(7):2319-25.

42. Freitas JB, Naves MMV. Composição química de nozes e sementes comestíveis e sua relação com a nutrição e saúde. Rev Nutr. 2010;23(2):269-79. http://dx.doi.org/10.1590/\$1415-52732010000200010

43. Institute of Medicine. Dietary reference intakes for vitamin A, vitamin K, arsenic, boron, chromium, copper, iodine, iron, manganese, molybdenum, nickel, silicon, vanadium, and zinc. Washington (DC): National Academy Press; 2002 [cited 2017 Apr 7]. Available from: https://www.nap.edu

44. Institute of Medicine. Dietary reference intakes for water, potassium, sodium, chloride, and sulfate. Washington (DC): National Academy Press; 2004 [cited 2017 Apr 7]. Available from: https://www.nap.edu 
45. Padovani RM, Amaya-Farfán J, Colugnati FAB, Domene SMA. Dietary reference intakes: aplicabilidade das tabelas em estudos nutricionais. Rev Nutr. 2006;19(6):741-60. http://dx.doi.org/10.1590/S1415-527 32006000600010

46. Mao X, Hua Y, Chen G. Amino acid composition, molecular weight distribution and gel electrophoresis of walnut (Juglans regia L.) proteins and protein fractionations. Int J Mol Sci. 2014:15(2):2003-14.

47. Food and Agriculture Organization. Protein quality evaluation: United Nations Report of a joint FAOMHO expert consultation. Rome: FAO; 1991.

48. Pires CV, Oliveira MGA, Rosa JC, Costa NMB. Qualidade nutricional e escore químico de aminoácidos de diferentes fontes protéicas. Ciênc Tecnol Aliment. 2006;26(1):179-87.

49. Hiane PA, Macedo MLR, Silva GM, Braga Neto JA. Avaliação nutricional da proteína de amêndoas de bocaiúva, Acrocomia aculeata (Jacq.) Lodd, em ratos Wistar em crescimento. Bol Ceppa. 2006;24(1):191-206.

50. Lujan DLB, Leonel AJ, Bassinello PZ, Costa NMB. Variedades de feijão e seus efeitos na qualidade protéica, na glicemia e nos lipídios sanguíneos em ratos. Ciênc Tecnol Aliment. 2008;28:142-9.

51. Tomé D. Digestibility issues of vegetable versus animal proteins: Protein and amino acid requirements: Functional aspects. Food Nutr Bull. 2013;34(2):272-4.

52. Monteiro MRP, Costa NMB, Oliveira MGA, Pires CV, Moreira MA. Qualidade protéica de linhagens de soja com ausência do Inibidor de Tripsina Kunitz e das isoenzimas Lipoxigenases. Rev Nutr. 2004;17(2):195-205. http://dx.doi.org/10.1590/S1415-52732004000200006

53. Souza JC, Fernandes DC, Naves MMV. Qualidade protéica de multimisturas distribuídas em Alfenas, Minas Gerais, Brasil. Rev Nutr. 2006;19(6):685-92. http://dx.doi.org/10.1590/S1415-52732006000600005

54. Monteiro MRP, Martino HSD. Avaliação nutricional e sensorial do extrato hidrossolúvel de soja. Rev Min Enf. 2006;10(2):113-7.

55. Roman JA, Sgarbieri VC. Obtenção e caracterização química e nutricional de diferentes concentrados de caseína. Rev Nutr. 2005;18(1):75-83. http://dx.doi.org/10.1590/\$1415-52732005000100007

Received: June 25, 2018

Final version: December 13, 2018

Approved: December 18, 2018 